\title{
INTEGRATING STATISTICAL EVIDENCE AND LEGAL THEORY TO CHALLENGE THE SELECTION OF GRAND AND PETIT JURORS*
}

\author{
Sara Sun Beale $\dagger$
}

I

\section{INTRODUCTION}

A defendant charged with a federal or state crime may employ statistical evidence to challenge the selection of the grand jury that indicts him or the petit jury that tries and convicts him. This article will consider three issues that arise in jury selection cases: (1) what are the proper figures upon which to base the statistical analysis; (2) what statistical method should be employed to analyze the data; and (3) what degree of disparity must be shown? ${ }^{1}$ For the most part judicial analysis of these questions has been the same in equal protection and fair cross section cases, although some differentiation is beginning to occur, and more is anticipated as the courts become more sophisticated in dealing with statistical evidence.

This article will argue that the propriety of using particular statistical evidence in jury selection cases cannot adequately be assessed without distinguishing between challenges based on the equal protection clause and those based on the constitutional or statutory right to a jury drawn from a fair cross section of the community. Although equal protection claims and fair cross section claims both require proof that a cognizable or distinct group has been underrepresented on the jury venires or the actual panels chosen, ${ }^{2}$ there is a significant difference between the elements of an equal protection and a fair cross section violation. Proof of purposeful discrimination, which is necessary to establish an equal protection vio-

\footnotetext{
Copyright (C) 1984

* This article has been printed with permission and adapted from Section 4:12 of a forthcoming book on grand jury law and practice being written by Sara Sun Beale and William C. Bryson for publication in 1985 by Callaghan \& Company, 3201 Old Glenview Road, Wilmette, Illinois 60091.

$\dagger$ Associate Professor of Law, Duke University School of Law.

1. For a general introduction to statistics suitable for a lawyer with no previous training in this field, see H. Blalock, SOCial Statistics (2d ed. 1972); and J. Ingram, Introductory Statistics (1974)

2. Castaneda v. Partida, 430 U.S. 482, $494-95$ (1977), holds that a prima facie showing of an equal protection violation may be established by evidence that a cognizable class has been substantially underrepresented in the jury venire or panels "over a significant period of time." A prima facie showing of a sixth amendment fair cross section violation may be established by evidence that the representation of a "distinctive group in the community" is not "fair and reasonable in relation to the number of such persons in the community," and that the underrepresentation "is due to systematic exclusion of the group in the selection process." Duren v. Missouri, 439 U.S. 357, 364 (1979).
} 
lation, ${ }^{3}$ is not necessary to establish a fair cross section violation. ${ }^{4}$ In federal prosecutions, the fifth and sixth amendments ${ }^{5}$ and the Jury Selection and Service Act of $1968^{\circ}$ require that both grand and petit jurors be drawn from a cross section of the community. In state prosecutions, the sixth amendment fair cross section standard is applicable to the selection of trial jurors. ${ }^{7}$ The selection of state grand jurors, in contrast, is subject only to the due process and equal protection clauses of the fourteenth amendment. ${ }^{8}$ Although there is no constitutional requirement that state grand jurors be selected from a fair cross section of the community, legislation in a number of states imposes a fair cross section requirement that is applicable to grand jury selection. ${ }^{9}$

\section{IDENTIFYING THE APPROPRIATE BASIS FOR COMPARISON}

The first and most fundamental question in cases involving statistical proof is what comparisons are probative. In many cases, including Castaneda v. Partida, ${ }^{10}$ the Supreme Court and the lower courts have permitted the defendant to compare

3. When the composition of a state grand jury is challenged, the disproportionate impact of facially neutral selection procedures is not sufficient to establish a constitutional violation. In Castaneda v. Partida, 430 U.S. 482 , 493 (1977), the Supreme Court held that in grand jury selection cases, as in other contexts, discriminatory purpose is an essential element of a violation of the equal protection clause.

4. Duren v. Missouri, 439 U.S. 357, 368 \& n.26 (1979).

5. The fair cross section requirement was first imposed pursuant to the Supreme Court's supervisory authority over the lower federal courts. Ballard v. United States, 329 U.S. 187, 192-94 (1946); Thiel v. Southern Pacific Co., 328 U.S. 217 (1946). In Taylor v. Louisiana, 419 U.S. 522 (1977), the Supreme Court concluded that the fair cross section requirement articulated in the supervisory power cases is a fundamental aspect of the jury trial guaranteed by the sixth amendment. Although most current federal cases rest on statutory rather than constitutional grounds, and the Supreme Court has never had occasion to consider the question, the cases that have considered the question have generally concluded that the fifth amendment grand jury clause requires that federal grand jurors be drawn from a fair cross section. Castaneda v. Partida, 430 U.S. 482, 509-10 (1977) (Powell, J., dissenting); Obregon v. United States, 423 A.2d 200, 205 n. 12 (D.C. Ct. App. 1980), cert. denied, 452 U.S. 918 (1981); cf. United States v. Herbert, 698 F.2d 981, 983-84 (9th Cir. 1983) (test for violations of fifth amendment, sixth amendment, and Jury Selection and Service Act the same). A few courts have concluded that the fair cross section principle is applicable to federal grand juries under the sixth amendment. See, e.g., United States v. Jenison, 485 F. Supp. 655, 660 (S.D. Fla. 1979). This is plainly unsound, since the jury trial clause of the sixth amendment is clearly limited to the trial jury, and no persuasive reason has been suggested for extending its reach to matters governed by the grand jury clause of the fifth amendment. Although the Jenison court gave no explanation for its failure to rely on the fifth amendment, there is one textual distinction between the fifth and sixth amendments that could be significant. Unlike the sixth amendment, the fifth amendment does not explicitly require review by an "impartial" grand jury. One justification for the imposition of the fair cross section requirement is that it ensures the impartiality of the trial jury.

6. Section 101 of the Jury Selection and Service Act of 1968, Pub. L. No. 90-274, 82 Stat. 53, 54 (codified at 28 U.S.C. $\$ 1861$ (1976)), provides that all litigants in federal courts "shall have the right to grand and petit juries selected at random from a fair cross section of the community in the district or division wherein the court convenes."

7. Taylor v. Louisiana, 419 U.S. 522, 528 (1975).

8. Unlike the jury trial clause of the sixth amendment, the grand jury clause of the fifth amendment has not been incorporated into the fourteenth amendment. Hurtado v. California, 110 U.S. 516 (1884); see Gerstein v. Pugh, 420 U.S. 103, 119 (1975); Beck v. Washington, 369 U.S. 541, 545 (1962).

9. Statutes requiring the selection of grand as well as petit jurors from a fair cross section of the community have been enacted in more than one-third of the states. See, e.g., ALA. CODE $\S 12-16-55$ (Cum. Supp. 1983): Colo. Rev. Stat. \$13-71-102 (1973); Del. Code AnN. tit. 10, §4501 (Cum. Supp. 1982): MD. CTs. \& Jun. Proc. Code Ann. § 8-102(a) (1980); N.Y. Judic. LaW $\S 500$ (McKinney Cum. Supp. 1983). The New Jersey courts have interpreted their state constitution as requiring grand jurors to be drawn from a fair cross section. State v. Porro, 158 N.J. Super. 269, 273, 385 A.2d 1258, 1260, appeal dismissed, 77 N.J. 504, 391 A.2d 517, cert. denied, 439 U.S. 1047 (1978).

10. 430 U.S. $482(1977)$ 
the percentage of minority jurors with the percentage of minority persons in the population as a whole." In recent years, however, a number of courts have accepted the prosecution's argument that the proper comparison is between the percentage of minority jurors and the percentage of minorities among the population eligible for jury service, not the population as a whole. ${ }^{12}$ The use of the eligible population rather than the population as a whole has strategic advantages for the prosecution and may have substantive advantages as well. As a procedural matter, it has often proved to be more difficult to establish the correct figures for the eligible population than for the minority population as a whole, which can readily be determined from census data. Where estimates of the percentage of the eligible population must be employed, they may be subject to challenge. ${ }^{13} \mathrm{Judge}$ Walter Gewin, in an analysis prepared for a committee of the Judicial Conference of the United States, ${ }^{14}$ suggested that it may be so difficult "to obtain full and accurate figures for jury eligibles" that requiring such evidence "may place an insuperable burden on a litigant." 15 Accordingly, he recommended that courts accept data on the general population, although a greater disparity could be required to establish a prima facie case than would be required if the jury pool were compared to the eligible population. ${ }^{16}$ Moreover, the demographics of the minority group are frequently not the same as those of the population as a whole, and in many cases a higher percentage of minority group members will be ineligible on grounds such as age, lack of United States citizenship, and inability to read and write the English language. ${ }^{17}$ If that is the case, a comparison of the jury lists with the eligible population will be less likely to show a substantial underrepresentation of minorities.

Courts have required the use of eligible population figures in both equal protection $^{18}$ and fair cross section cases. ${ }^{19}$ In statutory cases where the legislature

11. See, e.g., Turner v. Fouche, 396 U.S. 346 (1970); Eubanks v. Louisiana, 356 U.S. 584 (1958); Murrah v. Arkansas, 532 F.2d 105, 108 (8th Cir. 1976); United States v. Butera, 420 F.2d 564, 569-70 n.13 (1st Cir. 1970).

12. See, e.g., Moultrie v. Martin, 690 F.2d 1078, 1082 (4th Cir. 1982); United States v. Wesevitch, 666 F.2d 984, 990-91 (5th Cir. 1982); United States v. Brummit, 665 F.2d 521, 529-30 (5th Cir. 1981), cert. denied, 456 U.S. 977 (1982); United States $e x$ rel. Barksdale v. Blackburn, 639 F.2d 1115, 1124 (5th Cir.) (en banc), cert. denied, 454 U.S. 1056 (1981); United States v. Yazzie, 660 F.2d 422, 427 (10th Cir. 1981), cert. denied, 455 U.S. 923 (1982); United States v. Cabrera-Sarmiento, 533 F. Supp. 799, 804 (S.D. Fla. 1982).

13. Compare the majority and dissenting opinions in United States ex rel. Barksdale v. Blackburn, 639 F.2d 1115 (5th Cir.) (en banc), cert. denied, 454 U.S. 1056 (1981). See United States v. Cabrera-Sarmiento, 533 F. Supp. 799 (S.D. Fla. 1982).

14. Judge Gewin's memorandum is reprinted as an appendix to Foster v. Sparks, 506 F.2d 805, 811-37 (5th Cir. 1975).

15. Id. at 833 .

16. Id.

17. See, e.g., Moultrie v. Martin, 690 F.2d 1078, 1082 \& n.6 (4th Cir. 1982) (blacks made up 47\% of population, $40 \%$ of voting age population, and $38 \%$ of voting rolls; $38 \%$ is the appropriate basis for comparison where grand jurors chosen from voting rolls); United States ex rel. Barksdale v. Blackburn, 639 F.2d 1115, 1124 (5th Cir.) (en banc), cert. denied, 454 U.S. 1056 (1981)(depending upon which figures were used, the discrepancy in black representation might be as little as $4.34 \%$ or as much as $25.2 \%$ ); United States v. Cabrera-Sarmiento, 533 F. Supp. 799, 804 (S.D. Fla. 1982) (judicial notice of the fact that many Latins in Florida are not citizens or do not speak English).

18. See, e.g., Moultrie v. Martin, 690 F.2d 1078, 1082 (4th Cir. 1982); United States ex rel. Barksdale v. Blackburn, 639 F.2d 1115, 1124 (5th Cir.) (en banc), cert. denied, 454 U.S. 1056 (1981).

19. See, e.g., United States v. Brummit, 665 F.2d 521, 529-30 (5th Cir. 1981). 
established not only the cross section requirement but also the qualifications for jury service it may be appropriate to assume that the legislature intended to require only a cross section of the eligible population. In constitutional fair cross section challenges, however, the Supreme Court has approved the use of data based on the population as a whole, not merely the population that is eligible and not exempt, to establish a prima facie case. In Duren $v$. Missouri, ${ }^{20}$ the Court stated that "the fair-cross-section requirement involves a comparison of the makeup of jury venires or other sources from which jurors are drawn with the makeup of the community, not voter registration rolls." 21 If the qualifications for jury service cause significant underrepresentation, Duren requires that the qualifications be reviewed to determine whether they manifestly and primarily advance "a significant state interest." 22 Although Duren dealt only with the sixth amendment, its analysis clearly has implications for statutory cross section cases, because the statutory cross section provisions are likely to be construed as requiring constitutionally valid jury selection. Accordingly, if the constitutional measure requires comparison to the total population in the first instance, that may be the proper mode for statutory claims as well.

In equal protection cases, statistical evidence of underrepresentation is admitted as circumstantial proof of discriminatory purpose, and it has been suggested that an inference of discrimination is justified only if the minority members of the eligible population are underrepresented in the venire and on jury lists. ${ }^{23}$ Although this argument has some appeal, it was rejected by a majority of the Supreme Court in Castaneda v. Partida, ${ }^{24}$ which held that the defendant had established a prima facie case based on a comparison between the percentage of Mexican-Americans summoned for grand jury duty and the percentage of MexicanAmericans in the local population. ${ }^{25}$ The Court also referred to the total population rather than the eligible population when it described the elements of a prima facie case: "the degree of underrepresentation must be proved, by comparing the proportion of the group in the total population to the proportion called to serve as grand jurors." 26 Although Castaneda may be distinguishable in many cases if it is read narrowly, ${ }^{27}$ the majority seems to approve easing the challenger's burden of proof by accepting total population figures as sufficient to prove a prima facie

20. 439 U.S. 357 (1979)

21. Id. at 365 n.23 (emphasis added).

22. Id. at $367-68$.

23. See, e.g., Castaneda v. Partida, 430 U.S. 482, 504-05 (1977) (Burger, C.J., dissenting); United States ex rel. Barksdale v. Blackburn, 639 F.2d 1115, 1124 (5th Cir.) (en banc), cert. denied, 454 U.S. 1056 (1981).

24. 430 U.S. $482(1977)$

25. Id. at 486-88 \& n.8. Compare Justice Burger's dissenting opinion, id. at 504-05.

26. Id. at $494 \&$ n.8 (emphasis added).

27. The Court noted that in Texas the jury commissioners select potential jurors, whose qualifications are not tested until after the venire has been selected; accordingly, if the jury commissioners were not discriminating against Mexican-Americans, the number of Mexican-Americans on the venire should approximate the percentage in the general population. Id. at $486 \& \mathrm{n} .8$. Castanedo may thus be distinguishable in cases where eligibility is determined earlier in the selection process. Moreover, in Castaneda the state apparently raised this issue for the first time on appeal, and the evidence in the record was not sufficient to support its contentions. See id. at $486 \&$ n. 8 . Castaneda has been distinguished where the issue was raised in a timely fashion and supported by evidence that the percentagc of eligible minorities was 
case. ${ }^{28}$ This shifts the burden of proof to the prosecution-which may have greater access to the relevant data-to rebut the prima facie case by showing how and why a particular group was underrepresented. Dictum in Duren $v$. Missouri supports this reading of Castaneda. ${ }^{29}$

As a practical matter, since some courts may require the use of eligible population figures to establish a prima facie equal protection claim, and in other courts this data will clearly be relevant at the rebuttal stage, a challenger needs to develop evidence on the jury representation of minorities compared with their representation both in the eligible population and in the population as a whole. If a substantial deviation between the percentage of minority jurors and the percentage of eligible minorities can be shown, that establishes an even stronger prima facie case than underrepresentation compared to the population as a whole, and a smaller disparity may be sufficient to establish a prima facie case. ${ }^{30}$

\section{III}

\section{The Appropriate Method for Analyzing the Data}

The courts are currently divided on the proper method of analyzing the data in jury selection and composition cases. In early cases courts simply subtracted the percentage of minority group members on juries or venires from the percentage of minorities in the relevant population, expressing the difference in percentage terms. ${ }^{31}$ For example, if minority group members make up $25 \%$ of the eligible population but only $10 \%$ of the jurors, the difference is $15 \%$ underrepresentation. This method is often referred to as the absolute disparity test. Its advantages are the simplicity and ease of the calculation, which is easily understood by persons with no advanced training in mathematics or statistics. One major disadvantage of the absolute disparity test is that it is insensitive to the size of the group involved. A $10 \%$ absolute disparity may be a matter of great concern if it results in the total exclusion of a group that makes up only $10 \%$ of the population, but of much less significance when a group that constitutes $90 \%$ of the population makes up only $80 \%$ of the jury venire. The absolute disparity test treats these two cases as the same and also ignores the size of the population involved. ${ }^{32}$ Despite these problems, most courts continue to employ the absolute disparity standard, either

lower than the percentage of minorities in the general population. See, e.g., United States $e x$ rel. Barksdale v. Blackburn, 639 F.2d 1115, 1123 (5th Cir.) (en banc), cert. denied, 454 U.S. 1056 (1981).

28. See Castaneda v. Partida, 430 U.S. at $498-99$

29. In a footnote to its discussion of the disparity between the percentage of women on venires and the percentage of women in the census records, the Duren majority commented that it had relied upon census data in a prior equal protection decision, which, "like the case at hand, involved establishing as a benchmark the percentage of the excluded group in the relevant population." 439 U.S. at 365 (1979).

30. See Foster v. Sparks, 506 F.2d 805, 833 (5th Cir. 1975) (appendix).

31. See, e.g., Swain v. Alabama, 380 U.S. 202, 208 (1965).

32. For an influential critique of the absolute disparity method, see Finkelstein, The Application of Stalistical Decision Theory to the Jury Selection Cases, 80 HARV. L. REV. 338 (1966). Finkelstein was cited and relied upon by the Court in Castaneda v. Partida, 430 U.S. 482, 496 n. 17 (1977). See also Villafane v. Manson, 504 F. Supp. 78, 84-85 (D. Conn. 1980). For other critiques, see Kairys, Kadane, \& Lehoczky, Jury Representativeness: A Mandate for Multiple Source Lists, 65 CAL. L. REV. 776, 793-94 (1977), and Sperlich \& Jaspovice, Methods for the Analysis of Jury Panel Selections: Testing for Discrimination in a Series of Panels, $6 \mathrm{HAS}-$ TINGS CONST. L. Q. 787, 793-94 (1979). 
alone or in combination with other measures, in both equal protection and fair cross section cases. ${ }^{33}$

Because of the limitations of the absolute disparity standard, several other approaches have been suggested, each of which has earned a degree of judicial acceptance. ${ }^{34}$ The first of these alternative methods has been characterized as the ratio approach or the comparative disparity method. ${ }^{35}$ The starting point for calculating the comparative disparity is the absolute disparity; the absolute disparity is then divided by the percentage of minority group members in the population. ${ }^{36}$ For example, if a minority group makes up $25 \%$ of the population and minority jurors make up $10 \%$ of the venire, there is a $15 \%$ absolute disparity; this figure is then divided by $25 \%$ to calculate the comparative disparity, which is $60 \%$ underrepresentation. Although the comparative disparity approach responds to one shortcoming of the absolute disparity standard, it does not offer a satisfactory substitute. ${ }^{37}$ Where the group in question is very small, the comparative disparity analysis tends to magnify slight underrepresentations that could easily result from chance; when the group is very large the comparative method tends to validate deviations that are unlikely to have been produced by chance despite the fact that the disparity alters the representation of the average jury substantially. Although some courts have applied the comparative disparity analysis when the minority group is small, ${ }^{38}$ other courts have concluded the comparative approach is inap-

33. See, e.g., Gibson v. Zant, 705 F.2d 1543, 1545-46 (11th Cir. 1983); Machetti v. Linahan, 679 F.2d 236 (11th Cir. 1982). cert. denied, - U.S. -, 103 S. Ct. 763 (1983); United States v. Maskeny, 609 F.2d 183, 190 (5th Cir.), cert. denied, 447 U.S. 921 (1980); United States v. Musto, 540 F. Supp. 346, 355-56 (D.N.J., 1982), affd on other grounds sub nom. United States v. Aimone, 715 F.2d 822 (3d Cir. 1983); State v. Haskins, 188 Conn. 432, 450 A.2d 828, 836 (1982); State v. Hough, 299 N.C. 245, 262 S.E.2d 268 (1980). For further examples of courts using the absolute disparity standard see cases cited infra notes 60-65.

34. For a description and comparison of the methods, see United States v. Yazzie, 660 F.2d 422, 42627 (10th Cir. 1981), cert. denied, 455 U.S. 923 (1982); United States v. Clifford, 640 F.2d 150, 154-56 (8th Cir. 1981); United States v. Musto, 540 F. Supp. 346 (D.N.J. 1982); Villafane v. Manson, 504 F. Supp. 78, 83-87 (D. Conn. 1980); Kairys, Kadane \& Lehoczky, supra note 32, at 789-93, 799-801. The comparative disparity method was applied in Quadra v. Superior County, 403 F. Supp. 486, 495 \& n.9 (N.D. Cal. 1975), and the cases cited infra note 38 .

35. See, e.g., United States v. Clifford, 640 F.2d 150, 155 (8th Cir. 1981); United States v. Musto, 540 F. Supp. 346, 355 (D.N.J. 1982).

36. The calculation may be expressed by the following formula, which is taken from United States $v$. Clifford, 640 F.2d 150, 155 n.3:

\begin{tabular}{ll}
$\begin{array}{l}\text { Proportion of population } \\
\text { in the specified category }\end{array}$ & $\begin{array}{l}\text { Proportion of the source } \\
\text { in the specified category }\end{array}$ \\
\hline
\end{tabular}

Proportion of the population that is in the specified category

37. See D. Baldus \& J. Cole, Statistical Proof of Discrimination 45-47 (Cum. Supp. 1982) (criticizing trend toward the use of ratio measures). But see Kairys, Kadane, \& Lehoczky, supra note 32 , at 794-97 (arguing that the comparative disparity standard is "a clear, easily understood and used, and conceptually valid measure of representativeness," which would provide the best standard).

38. People v. Guzman, 89 A.D.2d 14, 24 \& n.8, 454 N.Y.S.2d 852, 859 (1982). It should be noted, however, that the court also expressly relied on testimony that the chance of the result in the case occurring randomly was less than one in one thousand. Id. The comparative disparity method is applied without explanation in State v. Acosta, 125 Ariz. 146, 148, 608 P.2d 83, 85 (Ariz. Ct. App; 1980), to groups making up $14.6 \%$ and $19.9 \%$ of the population, and in State v. Barrow, 239 Ga. 162, 236 S.E.2d 257, 260 (1977), to the underrepresentation of blacks, which made up $37.3 \%$ of the population. $C f$. United States v. Butler, 615 F.2d 685 (5th Cir.), denying reh'g of 611 F.2d 1066 (5th Cir.), cert. denied, 449 U.S. 830 (1980) (leaving open the question whether comparative disparity should be used in case of minority groups making up less 
propriate where the group is small because it "distorts reality." 39 A number of courts consider evidence of both comparative disparity and absolute disparity. ${ }^{40}$

Another technique that has attracted judicial support has been characterized as the absolute impact standard. ${ }^{41}$ The initial calculation is the same as that used for determining the absolute disparity; this number is then multiplied by the number of persons in a given array or panel. ${ }^{42}$ For example, if the absolute disparity is $10 \%$ underrepresentation, and the grand jury panel is made up of 23 persons, the absolute impact is a reduction of 2.3 minority grand jurors on an average panel. The disparity is measured in terms of its impact on juries, not simply percentages in the abstract. ${ }^{43}$ This analysis allows the courts to reject challenges when the challenged practices did not significantly alter the composition of the typical grand or petit jury. ${ }^{44}$ This technique is well adapted to determining whether a deviation from a statutory fair cross section requirement was sufficiently substantial to warrant relief, and it has generally been used in fair cross section cases. $^{45}$ It is less well suited to equal protection cases, where the ultimate issue is purposeful discrimination. Although the total exclusion of a small group over a period of years might have little impact, affecting only one or two persons on an average grand jury, the pattern of total exclusion might convincingly show discrimination. ${ }^{46}$ Since a defendant who establishes a prima facie equal protection

than 10\% of the population); Jordan v. State, 293 So.2d 131 (Fla. Dist. Ct. App. 1974) (applying the general reasoning of comparative disparity).

39. See, e.g., United States v. Musto, 540 F. Supp. 346, 355-56 (D.N.J. 1982), and cases cited; United States v. Facchiano, 500 F. Supp. 896, 899 (S.D. Fla. 1980).

40. See, e.g., United States v. Yazzie, 660 F.2d 422, 426-28 (10th Cir. 1981), cert. denied, 455 U.S. 923 (1982); United States v. Clifford, 640 F.2d 150, 155 (8th Cir. 1981); United States v. Test, 550 F.2d 577, 589 (10th Cir. 1976); of. Alexander v. Louisiana, 405 U.S. 625, 629 (1975) (describing reduction from $21 \%$ to $14 \%$, and from $14 \%$ to $7 \%$ in comparative terms).

41. This term is used in United States v. Yazzie, 660 F.2d at 426 n.3. Cases applying this approach include United States v. Suttiswad, 696 F.2d 645, 648-49 (9th Cir. 1982); United States v. Armstrong, 621 F.2d 951, 956 (9th Cir. 1980); United States v. Kleifgen, 557 F.2d 1293 (9th Cir. 1977); United States v. Potter, 552 F.2d 901, 905-06 (9th Cir. 1977); United States v. Goff, 509 F.2d 825, 826-27 (5th Cir.), cert. denied, 423 U.S. 857 (1975); United States v. Jenkins, 496 F.2d 57, 64-66 (2d Cir. 1974), cert. denied, 420 U.S. 925 (1975); United States v. Nordwall, 555 F. Supp. 37, 38-40 (D. Nev. 1982).

42. See United States v. Yazzie, 660 F.2d 422, 426 n.3 (10th Cir. 1981), cert. denied, 455 U.S. 923 (1982).

43. As the Ninth Circuit stated in United States v. Potter, 552 F.2d 901, 905 (9th Cir. 1977), the impact test looks "to people and not percentages."

44. See United States v. Suttiswad, 696 F.2d 645, 648-49 (9th Cir. 1982) (underrepresentation of 0.644 black person, 1.761 Spanish persons, and 1.081 Asian persons per grand jury not substantial); United States v. Armstrong, 621 F.2d 951, 955-56 (9th Cir. 1980) (less than one person per jury not substantial); United States v. Kleifgen, 557 F.2d 1293, 1297 (9th Cir. 1977) (underrepresentation of blacks by less than one person and males by approximately one person per grand jury not substantial); United States v. Potter, 552 F.2d at 905-06 (9th Cir. 1977)(less than one person per jury not significant); United States v. Goff, 509 F.2d 825, 826-27 (5th Cir.), cert. denied, 423 U.S. 857 (1975) (change of 1.4 persons per grand jury not significant); United States v. Jenkins, 496 F.2d 57, 64-66 (2d Cir. 1974) (one person per panel of 60 not significant); United States v. Nordwall, 555 F. Supp. 37 (D. Nev. 1982) (less than one person per jury not substantial).

45. The impact test has been used primarily, if not exclusively, in federal cases interpreting the fair cross section requirement of the Jury Selection and Service Act, 28 U.S.C. $\S 1861$ (1976); the courts have focused on indications of congressional intent to permit minor deviations but to forbid substantial deviations. See United States v. Goff, 509 F.2d 825, 826-27 (5th Cir.), cert. denied, 423 U.S. 857 (1975); United States v. Jenkins, 496 F.2d 57, 64-66 (2d Cir. 1974).

46. See Villafane v. Manson, 504 F. Supp. 78, 84 (D. Conn. 1980); cf. People v. Guzman, 89 A.D.2d $14,24-25,454$ N.Y.S.2d 852, 859 (1982) (11\% absolute disparity, but less than one in one thousand chance 
violation is not required to show prejudice as a result of discriminatory grand jury selection, ${ }^{47}$ the number of jurors who might have been affected should not be relevant.

The last approach, which was applied by the Supreme Court in Castaneda $v$. Partida, ${ }^{48}$ uses statistical formulas to calculate the "standard deviation," a measure used by statisticians to determine whether the difference between two populations is likely to have been the result of chance. A standard deviation has been defined as "the measure of the predictable fluctuation in a random selection process." 49 For example, if a coin is flipped ten times, and the process is repeated several times, it is likely that the results will vary slightly for each series even if the process is entirely random. The standard deviation measures the mathematical probability that a nonbiased selection system would produce any fluctuation observed between the actual results and the predicted result of five heads and five tails in each series. ${ }^{50}$ As the number of standard deviations increases, the probability that a nonbiased selection system would produce the observed result decreases. ${ }^{51}$

The standard deviation analysis has two principal advantages. The first advantage is that the statistical model itself can be adjusted to take into account sample size and the size of the relevant groups. ${ }^{52}$ Second, the model calculates the likelihood that a nonbiased selection system would produce the actual result. Evidence that the chance of this composition occurring without purposeful discrimination is as small as $1 \%$ or $0.1 \%$ is obviously strong circumstantial evidence of discriminatory purpose. Accordingly, the standard deviation test is well suited to equal protection cases, where the challenger must prove purposeful discrimination. The Court used the standard deviation analysis for that purpose in Castaneda, stating that, as a general rule for large samples, "if the difference between the expected value and the observed number is greater than two or three standard deviations, then the hypothesis that jury drawing was random would be suspect to a social scientist." 53 Since the decision in Castaneda a number of lower courts have concluded that the standard deviation analysis should be followed in equal protec-

of this result occurring by chance; on a 23 person grand jury, this would have an absolute impact of 2.53 persons)

47. See Rose v. Mitchell, 443 U.S. 545, $551-59$ (1979).

48. 430 U.S. $482,496-97$ n.17 (1977).

49. EEOC v. American Nat'l Bank, 652 F.2d 1176, 1191 (4th Cir. 1981), cert. denied, - U.S. -, 103 S. Ct. 235 (1982). See D. Baldus \& J. Cole, Statistical Proof of Discrimination 359 (1980).

50. The formula for calculating the standard deviation is described in Castaneda v. Partida, 430 U.S. at 497 n.17, and Sugrue \& Fairley, The Case of Unexamined Assumptions: The Use and Misuse of the Statistical Analysis of Castaneda/Hazelwood in Discrimination Litigation, 24 B.C.L. REv. 925, 929-35 (1983). Although the Court did not discuss this problem, Sugrue and Fairley explain that the calculations are different where more than one minority group is involved. Id. at 948-53.

51. When the sampling distribution has a normal bell-shaped curve, $68 \%$ of the cases are within one standard deviation, plus or minus, of the mean; 95\% of the cases fall within two deviations plus or minus, and $99.5 \%$ fall within three standard deviations. D. BALDUS \& J. ColE, supra note 49, at 295-97.

52. See Moultrie v. Martin, 690 F.2d 1078, 1083-84 \& n.10 (4th Cir. 1982) (discussing adoption of formula for small sample sizes).

53. 430 U.S. at 497 n.17. For a description of these probabilities, see supra note 51 . 
tion challenges, ${ }^{54}$ and it has also been used by at least one court in a fair cross section case. ${ }^{55}$

In addition to the standard deviation analysis discussed above, other forms of statistical analysis may be used to determine the probability that random selection would produce a given sequence of juries with a particular composition. For example, this analysis provides a way to calculate the likelihood that random selection would produce a series of eight grand juries, each of which had two blacksno more and no less. ${ }^{56}$

\section{IV}

\section{The Degree of Disparity Necessary to Establish a Prima FACIE CASE}

The final question raised by cases involving statistical proof of disparity is how great a disparity must be shown to establish a prima facie case. No categorical answer to this question is possible. Both legislatures ${ }^{57}$ and courts have been reluctant to announce fixed mathematical standards for jury selection cases, preferring an approach that evaluates the significance of any statistical disparity in context. ${ }^{58}$ Moreover, the different measures of disparity are not directly comparable. A case holding that a $30 \%$ comparative disparity was not significant would not be precedent for upholding a $30 \%$ absolute disparity. ${ }^{59}$ Although the use of different measures and the lack of clear guidelines has led to considerable confusion in the cases, some rules of thumb have emerged, particularly with regard to the absolute disparity and standard deviation measures.

54. See, e.g., Moultrie v. Martin, 690 F.2d 1078, 1082-85 (4th Cir. 1982); Villafane v. Manson, 504 F. Supp. 78, 84-88 (D. Conn. 1980).

55. People v. Buford, 132 Cal. App. 3d 288, 297-98, 182 Cal. Rptr. 904, 909-10 (1982).

56. In State v. Barksdale, 247 La. 198, 170 So.2d 374 (1964), cert. denied, 382 U.S. 921 (1965), after the Supreme Court held that the total exclusion of blacks in the parish violated the fourteenth amendment, nine grand juries were chosen, including eight with two black members and one with one black member. This case was used as an illustration of chi-square analysis in Finkelstein, supra note 32, at 347-48, 365-73. More recently, a divided en banc court upheld the same conviction, rejecting, inter alia, the contention that a prima facie case of discrimination had been established by evidence of the sequence of selections. United States ex rel. Barksdale v. Blackburn, 639 F.2d 1115, 1127-28 (5th Cir.) (en banc), cert. denied, 454 U.S. 1056 (1981). In effect, the majority accepted the statistical evidence as proof that the selection process was not neutral, but found that this did not justify an inference of discriminatory purpose. The majority noted that some of the judges who selected the jurors testified that they made special efforts to include blacks. Id. at 1128. Since the evidence of nonrandomness was equally consistent with an effort to discriminate against blacks or to ensure their representation, Barksdale had not carried his burden of proof. Id. Although chi-square analysis has not been used in many jury selection cases, it has been used in employment discrimination cases. For a helpful discussion, see 3 A. LARSON, EMPLOYMENT DISCRIMINATION $\S 74.61$ (1981). For a further discussion of methods to test for discrimination in a series of jury panels, see Sperlich \& Jaspovice, supra note 32 , at 787.

57. The legislative history of the Jury Selection and Service Act of 1968, 28 U.S.C. $\$ \S 1861-1874$ (1976), indicates that Congress intended "to leave the definition of 'substantial' to the process of judicial decision." S. REP. NO. 891, 90th Cong., lst Sess. 17 (1967).

58. In Alexander v. Louisiana, 405 U.S. 625, 630 (1972), the Supreme Court stated that it had "never announced mathematical standards for the demonstration of 'systematic' exclusion of blacks, but ha[d], rather, emphasized that a factual inquiry is necessary in each case that takes into account all possible explanatory factors." See also Foster v. Sparks, 506 F.2d 805, 816-19 (appendix).

59. Cf. Quadra v. Superior Court, 403 F. Supp. 486, 495 n.9 (N.D. Cal. 1975) (previous absolute disparity cases provide little guidance for court applying comparative disparity analysis). 
The lower federal courts and the state courts generally have concluded that when the absolute disparity test is applied, a disparity of $10 \%$ or less is not sufficient to establish a prima facie case in either equal protection or fair cross section cases. ${ }^{60}$ The author has discovered no case in which a court applying only the absolute disparity analysis found a disparity of less than $10 \%$ to be significant. The origin of the $10 \%$ figure is the Supreme Court's statement in Swain v. Alabama that "[W]e cannot say that purposeful discrimination based on race alone is satisfactorily proved by showing that an identifiable group in the community is underrepresented by as much as 10\%." 61 Although disparities between $10 \%$ and 15\% have been found significant in a few cases, ${ }^{62}$ several courts have held disparities in this range insufficient to establish a prima facie case of either an equal protection or a fair cross section violation. ${ }^{63}$ Absolute disparities between $15 \%$ and $20 \%$ have generally been deemed significant, ${ }^{64}$ and disparities of more than $20 \%$ have almost universally been deemed sufficient to establish a prima facie case. ${ }^{65}$

An inflexible application of the $10 \%$ cutoff-or any other rule of thumb in using the absolute disparity test - is difficult to justify in either equal protection or fair cross section cases. The significance of a $10 \%$ disparity varies depending upon both the percentage of the minority group in the population and the size of the relevant sample. For example, assume that in a jurisdiction with a discretionary selection process, a group making up $8 \%$ of a very large population has been totally excluded from jury service for a period of years. In that context, the $8 \%$ absolute disparity is strong circumstantial evidence of intentional discrimination, which is the ultimate issue in equal protection cases. Moreover, the total loss of the perspective of a distinct group making up $8 \%$ of the population should be significant for purposes of fair cross section analysis.

60. See, e.g., United States v. Hawkins, 661 F.2d 436, 442 (5th Cir. 1981), cert. denied, 456 U.S. 991 (1982); United States v. Clifford, 640 F.2d 150, 155 (8th Cir. 1981); United States ex rel. Barksdale v. Blackburn, 639 F.2d 1115, 1126-27 (5th Cir.) (en banc), cert. denied, 454 U.S. 1056 (1981); United States v. Butler, 611 F.2d 1066, 1069-70 (5th Cir.), reh'g denied, 615 F.2d 685 (5th Cir.), cert. denied, 449 U.S. 830 (1980); United States v. Test, 550 F.2d 577, 587 (10th Cir. 1976); United States v. Musto, 540 F. Supp. 346 , 356 (D.N.J. 1982), affd on other grounds sub nom. United States v. Aimone, 715 F.2d 822 (3d Cir. 1983); United States v. Haley, 521 F. Supp. 290, $292-93$ (N.D. Ga. 1981); United States v. Facchiano, 500 F. Supp. 896, 899 (S.D. Fla. 1980); State v. Haskins, 188 Conn. 432, 440, 450 A.2d 828, 836 (1982); State v. Robinson, 417 A.2d 953, 959-60 (Del. Super. Ct., 1980); State v. Avery, 299 N.C. 126, 134, 261 S.E.2d 803, 808 (1980).

61. Swain v. Alabama, 380 U.S. 202, 208-09 (1965).

62. See, e.g., Jones v. Georgia, 389 U.S. 24 (1967) (14.7\%); Sims v. Georgia, 389 U.S. 404 (1967) (14.6\%); Murrah v. Arkansas, 532 F.2d 105, 108-10 (8th Cir. 1976) (disparities of $12.48 \%$ and $14.11 \%$ suffcient where subjective criteria used); Preston v. Manderville, 428 F.2d 1392 (5th Cir. 1970) (14.3\%); Sanford v. Hutto, 394 F. Supp. 1278, 1282-84 (E.D. Ark., 1975) (14\% where discretionary selection system used).

63. See, e.g., Turner v. State, 258 Ark. 425, 527 S.W.2d 580 (1975) (12.5\%); State v. Brower, 289 N.C. 644, 224 S.E.2d 551 (1976) (11\% discrepancy and no other evidence of discrimination).

64. See, e.g., Alexander v. Louisiana, 405 U.S. 625, 629-32 (1972) (16\%); Whitus v. Georgia, 385 U.S. 545, 552 (1967) (18\%); Waters v. State, 271 Ark. 33, 38-39, 607 S.W.2d 336, 339-40 (1980) (15.82\%).

65. See, e.g., Duren v. Missouri, 439 U.S. 357, 365-66 (1979) (39\%); Taylor v. Louisiana, 4 I9 U.S. 522 , 524-26 (1975) (43\%); Turner v. Fouche, 396 U.S. 346, 359 (1970) (23\%); Gibson v. Zant, 705 F.2d 1543, 1547 (11th Cir. 1983) (20\%-38\%); Machetti v. Linahan, 679 F.2d 236, 240-41 (11th Cir. 1982), cert. denied, - U.S. - 103 S. Ct. 763 (1983) (36\% and 42\%); Porter v. Freeman, 577 F.2d 329 (5th Cir. 1978) (20.4\%); Spratley v. Paderick, 528 F.2d 733, 734 (4th Cir. 1975) (28\%); Barrow v. State, 239 Ga. 162, 165,236 S.E.2d 257, 260 (1977) (34.3\% disparity for grand jury). 
Accordingly, many courts have recognized that the absolute disparity that is necessary to establish a prima facie case should vary from case to case. ${ }^{66}$ In equal protection cases a smaller disparity may be sufficient to establish a prima facie case in a system where there are substantial opportunities for discrimination. ${ }^{67}$ In a system where jurors are selected at random from source lists compiled without discrimination, a greater disparity should be necessary to establish a prima facie case. ${ }^{68}$ A smaller absolute disparity should also be significant in equal protection cases if the comparison is made between minority jurors and eligible minorities, not all minorities in the population as a whole. ${ }^{69}$

Should the same degree of disparity be required to establish a fair cross section violation and an equal protection violation? Does it matter whether it is a statutory or constitutional fair cross section requirement? Although the courts have generally assumed that the same standard should apply regardless of the claim, ${ }^{70}$ that conclusion is questionable. In equal protection cases, statistical disparity is relevant only as circumstantial proof of intent; ${ }^{71}$ accordingly, if there is other evidence of intent, a smaller disparity may be sufficient to establish a prima facie case. But in fair cross section cases, intent and whether the selection process offers opportunities for discrimination are irrelevant; the only question in the first instance is whether a group's representation on the jury list is fair and reasonable in proportion to the group's size. ${ }^{72}$ A disparity too small to raise a presumption of discrimination may nevertheless infringe the values protected by the fair cross section requirement. A relatively small absolute disparity could result in the exclusion of most or all of the members of a small group, resulting in the total absence of their distinct perspective from the jury pool. And even though most courts have simply assumed that the same degree of disparity must be established to show a violation of a statutory fair cross section as to show a constitutional violation, ${ }^{73}$ that interpretation is difficult to reconcile with the broad remedial purposes of some or all of the fair cross section legislation, which generally manifests an intent to provide more than the constitutional minimum.

66. See, e.g., Bryant v. Wainwright, 686 F.2d 1373, 1377-78 (11th Cir. 1982); Murrah v. Arkansas, 532 F.2d 105, 109 (8th Cir. 1976); Blackwell v. Thomas, 476 F.2d 443, 447 (4th Cir. 1973). This is not inconsistent with Swain v. Alabama, 380 U.S. 202 (1965), which the Supreme Court has not regarded as establishing a general standard. Indeed, after the decision in Swain the Court stated in Alexander v. Louisiana, 405 U.S. 625 (1972), that it had never announced mathematical standards. Id. at 630 . See supra, note 57.

67. Sie, e.g., Murrah v. Arkansas, 532 F.2d 105, 109 (8th Cir. 1976); Blackwell v. Thomas, 476 F.2d 443, 446-47 \& n.7 (4th Cir. 1973) (disparities of 6\%, 9\%, and $12 \%$ in three years may be sufficient because of opportunity for discrimination in South Carolina system).

68. See, e.g., Blackwell v. Thomas, 476 F.2d 443, 447 n.7 (4th Cir. 1973) (10\% Swain standard appropriate where disparity results from objective criteria).

69. See Foster v. Sparks, 506 F.2d 805, 833 (5th Cir. 1975) (appendix).

70. See, e.g., United States v. Clifford, 640 F.2d 150, 155 (8th Cir. 1981) (following equal protection cases in statutory and constitutional fair cross section cases); United States v. Musto, 540 F. Supp. 346,356 (D.N.J. 1982), affd on other grounds sub nom. United States v. Aimone, 715 F.2d 822 (3d Cir. 1983) (following equal protection cases in statutory fair cross section cases); United States v. Haley, 521 F. Supp. 290, 292-93 (N.D. Ga. 1981) (following Swain in constitutional fair cross section case); United States v. Facchiano, 500 F. Supp. 896, 899 (S.D. Fla. 1980) (following Swain in statutory and constitutional fair cross section cases).

71. See Castaneda v. Partida, 430 U.S. 482, 494-95 (1977).

72. See Duren v. Missouri, 439 U.S. 357, 368 \& n.26 (1979)

73. See Foster v. Sparks, 506 F.2d 805, 816-18 (5th Cir. 1975) (appendix); see also cases cited supra note 70 . 
Although there are far fewer cases applying the comparative disparity standard, it does seem clear that, at least where very small groups were involved, the courts have been willing to tolerate greater percentage disparities in comparative disparity cases than in absolute disparity cases. Where very small groups were involved, courts have found that no prima facie case was established by evidence of comparative disparity as high as $59 \% .{ }^{74}$ The cases generally have not considered the challenger's theory in determining the degree of comparative disparity that would be permissible. But, just as in absolute disparity cases, in equal protection cases a smaller comparative disparity should be sufficient to establish a prima facie case in a key man or discretionary selection system than in a random selection system. ${ }^{75}$

The courts that have applied the impact standard have generally concluded that the challenger failed to prove a sufficient disparity when proportionate minority representation would have added only one or two additional minority jurors to a typical grand or petit jury. ${ }^{76}$ The decisions have not explained why the change of one or two members per panel is not significant. In cases involving only a challenge to the grand jury the courts have probably been influenced by the fact that the vote to indict need not be unanimous, and two negative votes would not prevent indictment. ${ }^{77}$ But even assuming that two additional minority votes would not be sufficient to block indictments, the addition of the minority jurors' views during deliberations might affect other grand jurors and be extremely significant. Especially in fair cross section cases the introduction of a distinct perspective is important even if it cannot be shown that it will change the outcome in particular cases. Moreover, the addition of even one minority juror to the typical trial jury could have a significant impact in any jurisdiction with a provision similar to Fed. R. Crim. P. 31(a), which requires a unanimous verdict.

The Supreme Court's statement in Castaneda $v$. Partida that a difference "greater than two or three standard deviations" is significant ${ }^{78}$ has generally been followed by the courts that have applied standard deviation analysis. ${ }^{79}$ There are two principal difficulties with this approach. First, the Court's statement in Castaneda is ambiguous. Can a disparity of two standard deviations be significant? Or is there some point between two and three standard deviations where the dis-

74. See, e.g., United States v. Test, 550 F.2d 557, 589 (10th Cir. 1976) (comparative disparities of 33\% for Chicanos and 59\% for blacks; absolute disparities 3.43\% and 1.54\%). Compare Barrow v. State, $239 \mathrm{Ga}$. 162, 165, 236 S.E.2d 257, 260 (1977) (38\% underrepresentation of blacks, who made up 37\% of the population, sufficient; absolute disparity, which was not calculated by the court, was $14.4 \%$ ). $C f$. State v. Acosta, 125 Ariz. 146, 148, 608 P.2d 83, 85 (Ariz. Ct. App. 1980).

75. See People v. Guzman, 89 A.D.2d 14, $24-25$ \& n.8, 454 N.Y.S. 2d 852, 859 (1982) (prima facie case shown by comparative disparity of $76 \%$ where absolute disparity of only $11 \%$ but less than one chance in one thousand that disparity would occur by chance in a random selection system).

76. See cases cited supra note 44.

77. Although the number of grand jurors and the number who must concur in an indictment varies from state to state, no state requires a unanimous vote of the grand jury to indict. The federal courts and a number of states follow the common law rule of requiring 12 of 23 grand jurors to concur in order to find an indictment. See, e.g., FED. R. Crim. P. 6(a) \& (f) (1976); GA. CodE § 15-12-61 (a) (1982); ILL. REV. STAT. ch. $38 \S \S 112-2(a), 112-4(d)(1980)$.

78. 430 U.S. 482,497 n.17 (1977).

79. See, e.g., Moultrie v. Martin, 690 F.2d 1078, 1083-85 (4th Cir. 1982); Hillery v. Pulley, 563 F. Supp. 1228, 1243-44 (E.D. Cal. 1983). 
parity becomes significant? If so, what is that point? Is a disparity of more than three standard deviations to be treated differently than a disparity of more than two but less than three standard deviations? At least one court has interpreted Castaneda as holding that a disparity of two standard deviations is insufficient as a matter of law to establish a prima facie equal protection claim. ${ }^{80}$ The court did not explain why a prima facie case could not be based on evidence that there was only a $5 \%$ probability that a nonbiased system would produce this result ${ }^{81}$ The second difficulty with the two to three standard deviation rule in Castaneda is that, by its own terms, it applies only to "large" samples. ${ }^{82}$ The Court did not, however, define what large means in this context, nor did it discuss what exceptions it would recognize to this "general" rule.

\section{Conclusion}

The use of statistical evidence requires courts to employ unfamiliar concepts. Other articles in this symposium emphasize the importance of an understanding of statistical terms of art ${ }^{83}$ Although a review of the jury selection cases reveals some instances in which courts have misunderstood statistical evidence, or have been unsophisticated in exploiting the evidence, this review also reveals a degree of inattention to legal theory and precedent. The challenge for counsel and the courts is not only to digest the unfamiliar evidence, but also to employ that evidence with greater attention to the distinction between equal protection and fair cross section theory, and the possible distinction between constitutional and statutory fair cross section standards.

80. Boykins v. Maggio, 715 F.2d 995 (5th Cir. 1983). For a brief critique of the two or three standard deviation rules of thumb, see Kaye, The Numbers Game: Statistical Inference in Discrimination Cases, $80 \mathrm{MiCH}$. L. REv. 833, 836-42 (1982).

81. For a discussion of the proper treatment of statistical evidence of a disparity between two and three standard deviations in the employment discrimination context, see Gay v. Waiters' \& Dairy Lunchmen's Union, 694 F.2d 531, 551-52 (9th Cir. 1982), and EEOC v. American Nat'l Bank, 652 F.2d 1176, 1192 (4th Cir. 1981), cert. denied, - U.S. -, 103 S. Ct. 235 (1982).

82. 430 U.S. at 497 n.17; see also Moultrie v. Martin, 690 F.2d 1079, 1083-84 \& nn.7, 10 (4th Cir. 1982); Villafane v. Manson, 504 F. Supp. 78, 86-87 \& n.14 (D. Conn. 1980); see generally Sugrue \& Fairley, supra note 49 , at $958-59$.

83. For an especially useful discussion, see Kaye, Statistical Significance and the Burden of Persuasion, LAw \& Contemp. Prob., Winter 1984, at 13. 
